\title{
PREFERMENT OF RELIGIOUS INSTITUTIONS IN TAX AND LABOR LEGISLATION
}

\author{
Monrad G. Paulsen*
}

The great majority of persons agree that the church and the state should remain separated in the United States. Yet it is also generally agreed that religious institutions should be encouraged by relieving them from statutory burdens which other groups in the nation ordinarily bear. The traditional exemption of the church from taxation of its property and income is the principal example of the sheltered position of religious organizations. ${ }^{1}$ Indeed, Dean Sperry of the Harvard Divinity School has called the tax exemption of churches "the most important governmental recognition of religion made in America. ..."2 Religious preferment is likewise manifested by according individuals and corporations who donate to religious institutions a deduction from their otherwise taxable property and income. Certain statutes regulating employers' relationships with their employees also contain exceptions in favor of religious groups.

I

\section{The Tax Exemptions}

In the federal tax system corporations, funds, and foundations "operated exclusively for religious, charitable, scientific, literary, or educational purposes" are exempted from the provisions of the federal income tax, provided "no substantial part of the activities ... [are for] carrying on propaganda, or otherwise attempting, to influence legislation." "Religious or apostolic associations or corporations ... even if such associations or corporations engage in business for the common benefit of the members . . ."4 are also exempt from income taxation, as are "corporations organized for the exclusive purpose of holding title to property, collecting income therefrom, and turning over the [net income] . . . to an organization which itself is exempt from the tax...."5 The fair rental value of a parsonage to a minister of religion is exempt from income taxation. ${ }^{6}$

Not only are these religious organizations themselves unburdened by federal tax obligations but, within limitations, gifts of tax-free income may be made by taxpayers

- A.B 1940, J.D. 1942, University of Chicago. Assistant Professor of Law, Indiana University School of Law.

${ }^{2}$ A general discussion is to be found in William G. Torpey, Judicial Doctrines of Religious Fughts in Americs c. VI (1948). See also Killough, Exemptions to Educational, Philanthropic and Religious Organizations, in Tax Exemptions 23 (I939); Carl Zolmmann, American Church Law c. Io (I933).

${ }^{2}$ Willard L. Sperry, Religion in America 60 (1947).

- Id. $\$ \operatorname{ror}(\mathrm{I} 8)$.

Id. \$rox(14).

INT. Rev. CODE $\$$ ror (6).

Id. $\$ 22(\mathrm{~b})(6)$. 
to such organizations. Individual taxpayers are allowed a deduction not exceeding I5 per cent of their adjusted gross income for contributions to organizations which are tax exempt. ${ }^{7}$ Business corporations may take a similar deduction in the amount of 5 per cent of their net income. ${ }^{8}$ Gifts and bequests to tax-exempt institutions are deductible for purposes of the federal gift ${ }^{9}$ and estate ${ }^{10}$ taxes without limitation.

Those states which impose income, gift, inheritance and estate taxes grant exemptions and deductions similar to those found in the federal tax scheme. ${ }^{11}$ State tax laws also exempt both real and personal property of religious institutions from state and local tax levies. The authority for the exemptions, of course, rests wholly in statutory provisions, which are found in every state, or in constitutional prescriptions. The guarantee of religious tax exemption was considered of sufficient moment to be expressly dealt with in two-thirds of the state constitutions. ${ }^{12}$ Of these, sixteen require some form of tax exemption to be given, while the remaining sixteen are permissive.

The statutory and constitutional exemptions are of great variety. Most statutes limit the amount of tax-exempt property in one way or another. ${ }^{13}$ For example, the exemption may extend only to such property as is used for religious purposes, ${ }^{14}$ or to such property as is exclusively used for religious purposes. ${ }^{15}$ A statute may limit the tax-exempt holdings of a church in terms of area ${ }^{16}$ or, as in New Hampshire, the limitation may be expressed in terms of the total value of property held. ${ }^{17}$ Drafting the limitations on tax-exempt property in terms of the use to which the property is put is a sure way to raise difficult questions for litigation. Is a parsonage exclusively used for housing a minister of religion entitled to the exemption? ${ }^{18}$ What of land owned by a church and held for its exclusive profit? ${ }^{19}$ What of a parking lot for churchgoers adjacent to an urban church? ${ }^{20}$ These questions will not be resolved in this paper, but should serve to remind one of the limits within which property tax exemptions operate.

\section{II}

\section{The Problem of the Constitution}

The First Amendment to the Federal Constitution provides in part that Con-

${ }^{7}$ Id. $\$ 23(0)$.

${ }^{8} I d . \$ 23(\mathrm{q})$.

'1d. $5 \mathrm{ro0} 4(\mathrm{a})(2)$.

${ }^{20} 7 d$. $\$ 8 \mathrm{r2}$ (d).

${ }^{21}$ E.g., income tax: N. Y. TAX LAW $\$ 360$ (10) (b); IowA Code $\$ 422.9$ (6b) (1946); estate tax: N. Y. TAx LAW \$249 c (3); inheritance tax: IowA CODE $\$ 450.4$ (2) (1946).

${ }^{13}$ See TORPEY, op. cit. stupra note $\mathrm{I}$, at $\mathrm{I} 73 \mathrm{n}$. Io.

${ }^{13}$ Minnesota seems to have no limitation on the amount of tax-exempt church-owned property. See Minn. Stat. Ann. \$272.02 (West, 1945). However, it has been suggested that actually the Minnesota courts do limit the exemption to property used for religious purposes. Note, Exemption of Property Owned of Used by Religious Organizations, Ix MrNw. L. Rev. 54I (1927).

${ }^{21}$ E.g., INd. ANn. Stat. \$64-20I (Burns I933).

${ }^{25}$ E.g., UTAH CODE ANN. 580-2-I (1943).

${ }^{10}$ E.g., WASH. REv. StAT. ANN. SIIIII (I939) (five-acre limitation).

${ }^{17} \mathrm{~N}$. H. Rev. Laws c. 73, \$25 (1942), limits religious tax exemptions to a valuation of $\$ 150,000$

${ }^{13}$ See First Congregational Church v. Board of Review, 254 Ill. 220, 98 N.E. 275 (19I2).

${ }^{20}$ See United Brethren v. Comm'rs, II5 N.C. 489, 20 S.E. 626 (1894).

${ }^{20}$ See Immanuel Presbyterian Church v. Payne, 90 Cal. App. 176, 265 Pac. 547 (r928). 
gress may make no law respecting the "establishment of religion" in the United States. ${ }^{21}$ Since 1925 the principles of the First Amendment have been recognized as applicable to the states. ${ }^{22}$ In addition, most state constitutions similarly forbid laws tending toward the establishment of religion by state governmens. A typical example is to be found in the constitution of Illinois, which provides that "no person shall be required to attend or support any ministry or place of worship against his consent. ..."23 Do these provisions of state and federal constitutions prohibit the general exemption of religious institutions from taxation?

Several state courts have answered that question in the light of their state constitutional provisions. In 1877 , the Supreme Court of Iowa, ${ }^{24}$ without divulging its grounds, held a statute exempting church property from taxation not a violation of the Iowa constitutional provision that "the General Assembly shall make no law respecting the establishment of religion ... nor shall any person be compelled to ... pay ... taxes, or other rates for ... the maintenance of any minister, or ministry."25 In Garrett Biblical Institute v. Elmhurst State Bank, ${ }^{26}$ a parallel case under the Illinois constitution, the Illinois court approved a similar statutory exemption for two principal reasons: ( $x$ ) the states in a Christian nation such as ours should encourage religious establishments to build up "the moral character and better impulses of the heart"; (2) the constitution is not violated if all religious denominations are encouraged by the state through tax exemption without discrimination.

In the light of the Everson and McCollum cases, decided under the Federal Constitution, neither ground of the Garrett opinion is sound. In Everson v. Board of Education, ${ }^{27}$ payment by a New Jersey school board compensating the parents of children attending parochial schools for the children's bus fare was held not to violate the Fourteenth Amendment to the Federal Constitution. The majority opinion of Justice Black viewed the provision for transportation payment as public welfare legislation applicable to children attending public schools as well as to those attending parochial institutions. He did indicate, however, that New Jersey in making the payments had gone to the "verge" of its constitutional power. Justice Black agreed with the dissenting justices that no tax funds might be appropriated for the support of any institution which teaches the tenets and faith of any church. "Neither a state nor the Federal Government can set up a church. Neither can pass laws which aid one religion, aid all religions, or prefer one religion over another."28 The three opinions written in this case are in agreement as to that fundamental. ${ }^{20}$ Quite

${ }^{21}$ U. S. CONST. AMEND. I.

${ }^{22}$ Gitlow v. New York, 268 U. S. 652, at 666 (I925). In 1875 President Grant suggested a constitutional amendment to provide ". . . that all church property shall bear its own proportion of taxation." Herman V. Ames, Proposed Amendments to the Constitumon 277 (x897).

${ }^{23}$ ILI. CoNST. Art. II, $\$ 3$.

${ }^{24}$ Trustees of Griswold College v. Iowa, 46 Iowa 275, 26 Am. St. Rep. 138 (1877).

${ }^{25}$ Iowa Const. Art. I, \$3.

${ }^{20} 331$ Ill. 308, I63 N.E. I (1928). See also Trustees of First Methodist Church v. Atlanta, 76 Ga. r8x ( 1886$)$.

${ }^{27} 330$ U. S. I (1947). $\quad{ }^{28} \mathrm{Id}$. at $\mathrm{r} 5$. (Italics supplied.)

20 "Of course, the state may pay out tax-raised funds to relieve pauperism but it may not under our 
clearly an allocation of state revenue to religious institutions would now be unconstitutional even if the appropriations were motivated by a desire to build character and even though portions of the expenditure were equally available to all religious bodies.

Although it is clear that the state may not directly support any religious institution by appropriations derived from tax funds, the result reached in the Garrett case may nevertheless be correct because a tax exemption is not a direct but rather an indirect support of religion. Such a verbal distinction would fail to recognize that there is no practical difference between making appropriations and failing to send a tax bill. In either event the church is given aid by the state.

After McCollum v. Board of Education ${ }^{30}$ the distinction between indirect and direct state support of religion will be hard to maintain. According to the McCollum case the aid which is unconstitutional if given a religious institution need not be in the form of directly appropriated tax funds. It is sufficient if the assistance received is the use of property which has been supplied by taxes. In the McCollum case the use of tax-supported school property for religious purposes was an important element in establishing the unconstitutionality of the "released time" system of religious instruction. Justice Black repeats the sentence quoted above from the Everson opinion, ${ }^{31}$ which certainly lends itself to the interpretation that indirect aids to religion are forbidden to the states equally with direct appropriations. ${ }^{32}$ Therefore neither the legislature's motivation in giving the exemption, the non-discriminate grant of the exemption to all religions, nor the indirect character of the exemption justifies the preferential tax status of religious groups under the Constitution.

Against these arguments stands the force of American history. Tax exemption for religious institutions has been the American practice since the disestablishment of the churches. Properties have been given, acquired, and held on the assumption that they are tax exempt. In view of this established custom and practice, the problem should be left to legislative judgment unless the tax exemption is seen to lead to an obnoxious union of church and state. The tax exemption during our history has not in fact begun a series of steps toward the establishment of religion. The

Constitution do so to induce or reward piety." Justice Jackson dissenting, id. at 25. Justice Rutledge expresses the same view: "[The Constitution] outlaws all use of public funds for religious purposes." Id. at 33 .

3033 U. S. 203 (1948).

${ }^{31}$ Id. at $2 \times 0$. According to the writer of a note, Establishment of Religion by State Aid, the statements made in the McCollum and Everson cases are broad enough to cover tax exemption: ". . tax exemption ... is also an apparently direct aid to religion which has seemingly been banned by the First and Fourteenth Amendments as construed in the McCollum and Everson cases." 3 Rutgers L. REv. I15, 122 (1949).

${ }^{32}$ The dissenting opinions in the Everson case also contain language capable of the same interpretation. ". . . the effect of the religious freedom Amendment . . . was to take every form of propagation of religion out of the realm of things which could directly or indirectly be made public business and thereby be supported in whole or in part at taxpayers' expense." Justice Jackson dissenting, Everson v. Board of Education, supra note 27 , at 26 . "The prohibition broadly forbids state support, financial or other, of religion in any guise, form or degree." Justice Rutledge dissenting, id. at 33 . 
state-granted benefit to the churches has remained largely in the tax field. As a practical matter, aid by tax exemption puts a very real limit on the total amount of support given religious institutions. The help is never more than sums saved because a generally applicable tax is not paid.

\section{III}

\section{The Problem of Justification}

In the course of English history religious institutions were not always free from compulsory payments to the state. The history of the English church clearly shows many instances in which the lords spiritual were called upon to contribute to the support of the temporal authority. ${ }^{33}$ In the American colonies, however, where the church was poor and an arm of the state itself, rather than a powerful rival, there was no thought of putting a tax upon the church or church property any more than a modern city would think of placing a tax upon its department of streets. ${ }^{34}$ The church not only was relieved from tax burdens in the American colonies but was itself supported by taxes imposed by the secular arm of the government. ${ }^{35}$ Even after religious freedom was achieved in the colonies, the several churches in the community were given the power to lay taxes upon their adherents and to collect them with the aid of the power of the state. ${ }^{38}$ The immunization of churches from taxation continued as a matter of practice even after complete disestablishment. ${ }^{87}$ Statutory authority for the exemption was late in appearance; for example, Massachusetts had no statutory exemption until 1837, New Hampshire until 1842, and New Jersey until $18_{5} \mathrm{r}^{38}$

Originally, the freedom of religious organizations and church property from taxation was taken as a matter of course, hardly needing justification. It was "so entirely in accord with the public sentiment, that it universally prevailed."30 Since the middle of the nineteenth century, however, many attacks have been made upon the tax-free position of the church, ${ }^{40}$ particularly in opposition to its tax-exempt real

${ }^{33}$ Adler, Historical Origin of the Exemption from Taxation of Charitable Institutions in TAx ExEMp. tTONS ON REAL Estate passim, esp. 34, 39, 43 (r922).

st "Prior to and at the time of the adoption of the constitution of 1784 and 1792 , public religious worship was very generally supported by a tax laid by the several towns. . . The support of the ministry and of houses of public worship was then on the same footing as that of schools, highways, and the support of the poor." Franklin Street Society v. Manchester, 60 N. H. 342, 347-8 (1880).

${ }^{35}$ Adler, supra note 33 , at 74 .

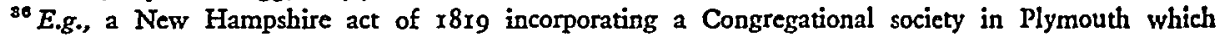
provided: ". . . the Wardens... [shall] assess the polls and ratable estate of the members of said Society their just and equal proportion of all sums of money ... 「voted by the society]. . . . the Collector of said Society . . . shall have the same power to collect the taxes to him committed, as the collectors of towns in this State by law have." 8 LAws OF NEw HAMPsHire 756 (I920).

st "Meeting houses and school houses, although not formally exempted by the tax laws in force prior to 1851 , were seldom if ever assessed in any part of the state." State v. Collector of Jersey City, 24 N. J. L. 108, 120 (Sup. Ct. 1853 ).

"Zotrasan,, Op. cit supra note I, at 329-30.

s9 State v. Collector of Jersey City, supra note 37 , at 120.

10 The history of a prolonged attack in a state legislature against religious tax exemptions is described in I JoHn E. BRINDLEY, History of TAXATTON IN IOWA c. I2 (I9II). 
property. These attacks have been based on two principal grounds: (I) Ideological (opposition to the influence exerted by the church and organized religion in a democratic society ${ }^{41}$ and the contention that unbelievers should not be forced to contribute to the church even indirectly) $;^{42}$ (2) Economic (revenue needed by the community is lost through religious exemptions)..$^{43}$ As a secondary consideration, a fear has been voiced that the tax exemption would leave a church reluctant to criticize state and federal governments. ${ }^{44}$ Furthermore, the exemption encourages the construction and maintenance of an excessive number of churches. ${ }^{45}$

In reply, the defenders of the exemption have been many and have used a formidable array of arguments. Religious institutions are said to be performing a portion of the state's work better than the state could do it. ${ }^{46}$ The performance of that duty should not be discouraged. The benefit which the state is said to receive from the moral instruction and character-building activities of religious associations justifies the exemption. ${ }^{47}$ By indirectly subsidizing religious institutions the state is devoting its funds to "higher purposes" than any which the state itself might serve. ${ }^{48}$

${ }^{1}$ See the following language in a petition to the legislature of Iowa: "Because by exempting church property from taxation the State is assisting to support sectarian religion, which is unconstitutional and foreign to the purposes for which our government was formed. . . Iowa State Register, Feb. I, I880, quoted in BrindLex, op. cit. supra note 40 , at 448. Cf. Mowny, Ought Chutch Property to Be Taxed, 55 Green Bag $4{ }_{4}$ (I903); Adler, supra note 33, at 77; Turano, Shall We Tax the Churches? I02 Forum II5 (1939); McAfee, Is It Fair to the American Community? 53 Christran Century 1356 (1936).

${ }^{12}$ See Stimson, The Exemption of Property from Taxation in the United States, I8 Mins. L. REV. 4II, 422 (1934); Stimson, The Exemption of Churches from Taxation, 18 TAxes $36 \mathrm{r}$ (1940); Hoke, Sixty Billion Dollars-Tax-Exempt, 35 AM. MERc. 222 (1935). Compare the following statement of the Rev. David Rhys Williams, a Unitarian pastor, reported in the daily newspapers of Rochester, N. Y., Jan. 4, 1947: "It is neither democratic nor chivalrous to tax any portion of the community, to support what is essentially a volunteer enterprise in which a large part of the community may not believe."

${ }^{13}$ Atkins, Tax Exemptions-A Key to Tax Reduction, 9 Tax Mag. I9 (193I); Churches Should Pay Taxes, 64 Christian Century 454 (r947). (This editorial attacks the tax exemptions on ideological grounds as well.) Various defenses of the exemption are advanced by the writers of several letters written in reply to the editorial. 64 Christian Century 56r (1947).

"See Cavert, Points of Tension between Church and State in America Today in Church and State. IN THE MODERN WORLD I6x, I74 (I937).

15 See Wirliam A. Brown, Church and State in Contemporary America I23 (I936); Cavert, supra note 44, at 775 ; Christian Century editorial, supra note 43 , at 455 .

${ }^{10}$ See John G. Saxe, Charutable Exemption from Taxation in New York State 45 (i933); Elior, op. cit. infra note 48; Brindery, op. cit supra note 40 , at 450 . "All these establishments [religious and charitable] ... are devoted, as well as the public property, to the attainment of the legitimate ends of government. ..." Trustees of First Methodist Church v. Atlanta, 76 Ga. 18x, I91 (1886).

${ }^{17}$ See Charles J. Tobin, William E. Hannan, and Leland L. Tolman, The Exemption from Taxation of Privately Owned Real Property 20 el seq. (1934); H. R. Rep. No. I860, 75th Cong., 3rd Sess. (1938), reprinted in I-2 Cum. Bull. 728 at 742 (1939); Zollmann, op. cit. stipra note I, at 327; Brindlex, op. cit. supra note 40, at 450 ; SAxE, op. cit. supra note 46 at $45-46$.

${ }^{48}$ The statement of Charles W. Eliot, President of Harvard College, made in 1874 to the commissioners of the Commonwealth of Massachusetts, is a classic discussion of the subject of charitable and religious tax exemptions. The following quotation is the most familiar portion of his statement: "To tax lands, buildings or funds which have been devoted to religious or educational purposes, would be to divert money from the highest public use,-the promotion of learning and virtue, - to some lower public use, like the maintenance of roads, prisons or courts, an operation which cannot be expedient until too large an amount of property has been devoted to the superior use." ExEMPtron From Taxation IN MASSAChUSETtS 20, 23 (I910). 
There is no estrangement between the church and the state; ${ }^{49}$ each is paramount in serving the ends of a portion of human life; each should be free to serve those ends without interference by the other. Thus the churches do not properly interfere with temporal affairs, and the state should not intrude into matters of the church even with its power of general taxation. ${ }^{50}$ The exemption is a fit recognition of the sanctity of religion. ${ }^{\text {s1 }}$

The defenders of the exemption doubt whether any important revenue is lost to the community through operation of the tax exemption. ${ }^{52}$ In their view the total value of church property is not great and certainly is not increasing in proportion to the value of all property in the community. ${ }^{63}$ To tax the churches would result in the double taxation of persons who contribute to them. ${ }^{54}$ On the other hand, because donations to churches are generally made by all taxpayers anyway, the effect of taxing church property would be negligible in its impact upon the expenditures of individuals. ${ }^{65}$ Indeed churches contribute to property values in the community by their very presence. ${ }^{56}$

Any defense of the tax exemption of religious organizations must recognize that the exemption is a subsidy from the state in direct proportion to the amount of taxable property or income which the organization has. Moreover, it is a subsidy which is not periodically reviewed and fixed by legislative bodies. In a society where the church and the state are presumably separated, there is no basis for believing the church to be doing a part of the state's work. The moral uplift of religious instruction and the "higher purposes" which religion serves are values which the state presumably could not properly undertake for itself. ${ }^{57}$ The state could not justify its own operation of religious institutions on that ground without seriously undercutting the policy embodied in the religious clauses of the First Amendment, now applicable to the states by way of the Fourteenth Amendment. While the church should be free from the control of the state, the state may not organize any church or churches in the pursuit of any ends, however desirable they may seem to be. Therefore, if religious organizations are looked upon solely as the teachers of religious doctrine and the custodians of religious practices, the tax exemptions are hardly justifiable.

Almost all tax exemptions, however, are granted to educational and charitable institutions as well as to religious organizations. Religion is not alone the object

\footnotetext{
${ }^{20}$ Hill, The Exemaption of Church Property from Taxation 6 et seq. (1876). Sec also Todin et al., op. cit. stupra note 47 , at 23 .

${ }^{50} \mathrm{HuLI}$, supra at 37. And see the remarks of Senator Laramie quoted in BRINDLEX, op. cit. stupra note 40 , at 266 .

oI See Report of the Commission on TAxation (Massachusetts) 75-76 (1897).

${ }^{62} \mathrm{FrLI}$, op. cit. supra note 49, at 28 et seq. See also the remarks of Judge Cuilen reported in Seventh New York State Conference on Thxation 234 (I9I7).

${ }^{t 3} \mathrm{HrLI}$, op. cit. supra note 49 , at 16 et seq. $\quad$ E⿺ BRINDLEX, op. cit. supra note 40 , at 450.

"I Thomas M. Cooley, Taxation, \$201, p. 430 (4th ed. 1924).

Eo ToBin et al., op. cit supra note 47 , at 56 .

${ }^{57}$ See discussion stipra p. 147.
} 
of preference in the tax statutes. Perhaps the most persuasive justification of the religious exemption can be made with this fact in mind. ${ }^{58}$ Justice Reed, dissenting in $M c$ Collum v. Board of Education, seems to defend the tax exemption in these terms:

It seems clear to me that the "aid" referred to by the Court in the Everson case could not have been those incidental advantages that religious bodies, with other groups similarly situated, obtain as a by-product of organized society. This explains the wellknown fact that all churches receive "aid" from government in the form of freedom from taxation. ${ }^{\text {g9 }}$

Not only are other institutions beneficiaries of tax preferment, but church organizations as part of their activities frequently perform many services identical with those performed by charitable and educational institutions. Like charities, churches give private relief, aid the fund-raising of private charities in general, and support through their church-sponsored organizations their own old people's homes, orphanages, hospitals, schools, and the like. ${ }^{60}$ Perhaps the tax exemption can be justified as the state's recognition of this aspect of a church's work, rather than in recognition of the teaching and practice of formal religion.

In more recent years the church's position as a tax-exempt institution has not been an important public question. Modern discussion of the exemption by public agencies has been most cautious. In a IgIg New Jersey Commission Report on the state's tax laws, the general question of tax exemption is discussed but no reference is found concerning the exemption of religious organizations, although the problem of exempting charitable organizations is reviewed. ${ }^{61}$ A similar I920 report made in New Mexico reveals the hopelessness with which some public bodies approach the exemption problem:

The exemption from the property tax ... while in our opinion quite illogical and provocative of much abuse, has apparently met with the general public approval and the support of churchgoers and other beneficiaries who are instrumental in the formation of public opinion. It seems useless to criticize these exemptions although it should be obvious that whatever reason may exist for holding this property as private property is equally good reason for paying taxes thereon. ${ }^{62}$

\footnotetext{
${ }^{58}$ See Cavert, supra note 44, at 216-2I7: "At the present time, I suppose, the churches are exempt from taxation just as one among many groups of non-profit agencies, including charitable, educational and other institutions. If the Church takes its place along with other non-profit agencies, I should say it is not receiving any distinctive favor." See also SAXE, op. cit. supra note 46 at 46 ; Hoff, Religious Freedom Under Our Constitutions, 3I W. VA. L. Q. 14, 33 (I924). An interesting example of the interrelationship between religious and educational tax exemption is found in a MEMORANDUM submitted in I939 by Teachers College of Columbia University, in which continued cancellation of water charges was sought on the ground that the college contributed to New York educational, charitable, and religious work.

${ }^{00} 333$ U. S. 203,249 (I948).

${ }^{\circ 0} \mathrm{~A}$ detailed account of the activities of churches in a typical community is found in $\mathrm{H}$. PArr. Douglass, The Springfield Church SuRver (esp. cc. VII, VIII, XI) (I926).

${ }^{\circ}$ Report of the Comaission to Investigate Tax Laws (igig). Custis, The State Tax Systens OF WasfnNGTON (IgI6), also contains no critical discussion of religious tax exemption.

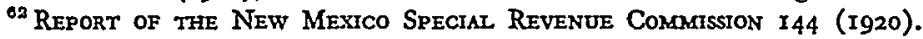


In 1927 a New York taxation committee in a preliminary report on Tax Exemption in the State of New York merely asked a question in its findings and recommendations: "Is it consistent with the separation of the church and the state to continue an indirect subsidy for religious institutions?"83 A 9933 survey of the Iowa revenue system made by the Brookings Institution also shows a reluctance to reopen argument concerning the question:

The legitimacy of exempting religious property was fought out in Iowa in the years following 1873 , with a final verdict in favor of the exemption. It is not likely that any different verdict would be rendered on this issue by the public today. Nevertheless, it is essential that property exemptions be strictly controlled and reluctantly granted if the integrity of the property tax is to be upheld. ${ }^{84}$

A general survey of clergymen and laymen published in 1936 revealed no dissatisfaction with the exemption even among such groups as the Unitarians, who traditionally are most opposed to any alliance between church and state. ${ }^{0 r}$

In considering the present position of religious tax exemption, the absence of contemporary critical discussion ${ }^{66}$ is most striking in view of the bitter controversy over the teaching of religion in the schools and the diversion of tax funds for the direct support of religious activity. The tax-exemption battle of the churches seems to have been won by exhaustion.

\section{IV}

\section{The Problem of Economics}

In December, 1875 , President Grant, in a message to Congress, made the following statement:

In 1850 , I believe, the church property of the United States which paid no tax, municipal or State, amounted to about $\$ 83,000,000$. In 1860 the amount had doubled; in 1875 it is about $\$ 1,000,000,000$. By 1900 , without check, it is safe to say this property will reach a sum exceeding $\$ 3,000,000,000$. So vast a sum, receiving all the protection and benefits of Government without bearing its proportion of the burdens and expenses of the same, will not be looked upon acquiescently by those who have to pay the taxes. In a growing country, where real estate enhances so rapidly with time, as in the United States, there is scarcely a limit to the wealth that may be acquired by corporations, religious or otherwise, if allowed to retain real estate without taxation. The contemplation of so vast a property

${ }^{\text {es }}$ P. II (1927).

o4 Report on a Survey of Administration in Iowa 33 (1933). See also Report op Commission on TAX Exemptions (Connecticut) rg (1925): “. . . your commission finds little disposition in Connecticut at this time to tax property devoted to religious use or pure benevolences which are supported by private contributions, and which benefit society as a whole."

os Brown, op. cit. supra note 45 , at $\mathrm{r} 6 \mathrm{r}$.

${ }^{\circ 6}$ See Cavert, supra note 44, at 2I7: "Probably the prevailing point of view is that the churches are good things; even if people don't belong to the church, they generally admit that churches accomplish worthwhile services in the community. So I do not now see any widespread criticism on this point." Agnes E. Meyer denies even the relevancy of the tax exempt status of churches to a discassion of Church-State problems. "The fact that church property is tax-exempt creates no relationship between Church and State." Meyer, The School, the State, and the Church, Atlantic Monthly, Nov. 1948, pp. 45,48 . 
as here alluded to without taxation may lead to sequestration, without constitutional authority and through blood.

I would suggest the taxation of all property equally, whether church or corporation, exempting only the last resting-place of the dead, and possibly, with proper restrictions, church edifices. ${ }^{\theta 7}$

To test whether the fears implied in this statement are justified and whether the growth of church wealth is a consequence of the church's exemption from taxation, it would be necessary to have a great many more facts than are actually available. The paucity of fact makes difficult any judgment about the economic effects of the tax exemption. Can one say that the failure of churches to bear their share of taxes results in a significant reduction of revenue?

The amount of income lost to the Federal Government by reason of the deductions allowed on an individual's income and gift tax returns for religious contributions cannot even be guessed. Yet some indication of the importance of these deductions appears when we compare the total charitable and religious deductions with the declared net income of individuals. In the years I924, I927, I928, I929, I940, and r94I, the total deduction claimed was over one-half billion dollars. ${ }^{68}$ These total deductions represent roughly 1.7 per cent to 2 per cent of each year's declared net income. From I939 to I94I, of the claimed deductions 60 to 70 per cent were taken on returns with net incomes of less than $\$ 5000 .^{69}$ It should be noted that the tax loss to the Government is less in these lower income brackets. In the case of the federal gift tax the charitable gifts in I939 were about fifty million dollars, or I3.2 per cent of the value of total gifts before exclusions. ${ }^{70}$ In I940 the percentage was 14.I per cent and in I94I only 6.5 per cent. ${ }^{71}$ These figures, of course, include the deductions claimed because of charitable, scientific, educational, and literary contributions as well as those to religious organizations. (The latest publication of the Treasury listing organizations to which contributions are tax-free ran from the American Cancer Society to the Zurbrugg Memorial Hospital, and included such organizations as the "Lorelei" Singing Society of Chicago.) ${ }^{72}$ Therefore, this information gives only little clue to the extent of contributions given to religious groups alone. At most we can say that tax-free religious contributions are less than the total amounts shown.

The facts concerning the federal estate tax are more revealing because the deductions for religious contributions are published separately. The following table ${ }^{73}$ indicates the relative importance of the religious deductions:

${ }^{67} 4$ CoNG. Rec. I75 (1875).

${ }^{\circ 8}$ StATISTICS OF INCOME FOR 1941, pt. 1, 217-223 (U. S. Treas. 1944).

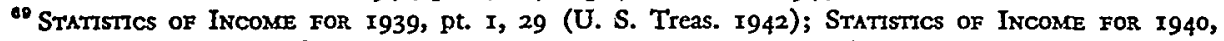
pt. I, 21 (U. S. Treas. I943); Statistics of InCOME FOR I94I, pt. I, 24 (U. S. Treas. I944).

${ }^{70}$ Stattstics of INCOME For 1939, pt. I, 285 (U. S. Treas. 1942).

72 Statistics of Income For 1940, pt. I, 229 (U. S. Treas. 1943); Statistics of INCOME FOR I941, pt. I, 272 (U. S. Treas. I944).

${ }^{72}$ Cumulative List of Organizations (U. S. Treas. 1946).

7a Taken from Statistics of INCONe, supra note 69: the I939 Report at 250; the 1940 Report at 200; the 1941 Report at 246. 
Returns

Filed in

Total Gross

Estate

I940

I94I

1942
$\$ 2,632,659,000$

$\$ 2,777,657,000$

$\$ 2,724,513,000$
Total Deductions

for Charity, Re-

ligion, etc.

$\$ 143,365,000$

$\$ 175,072,000$

$\$ 154,633,000$
Total Deductions for

Religious Contribution

$\$ 16,779,000$

$\$ 12,835,000$

$\$ 15,724,000$

In the estate tax area it is clear that the deductions for religious contributions are insignificant, revenue-wise, compared with the total deductions allowed for charitable, literary, scientific, religious, and educational purposes. Roughly, the religious deductions account for ro to 15 per cent of the total allowed deductions of a similar character.

Although the amount of revenue lost by allowing estate tax deductions for charitable and religious bequests may be relatively small, it should nevertheless be pointed out that in a few instances powerful and wealthy families have used the gift and estate tax exemptions to their advantage. The late Andrew Mellon left an estate of one hundred million dollars to the Andrew Mellon educational and charitable trust, of which his son, son-in-law, and attorney were trustees. ${ }^{74}$ Similarly, the late Henry Ford, Sr, transferred all of his non-voting stock in the Ford Motor Company to the Ford Foundation for charitable and educational purposes. ${ }^{75}$ Such a device allows a wealthy family to retain direction and control of its enterprise even though the financial fruits of the enterprise may be distributed for a charitable, educational, or religious purpose. Sound policy would require the placing of some limits upon the estate tax and gift tax deductions for this purpose. Perhaps the limitation should be similar to the 5 per cent limit allowed on an individual's income tax.

Information as to the economic importance of state exemption from taxation of real property held by religious bodies is more generally available. In New York in I920 the assessed value of the real property which was subject to taxation was $\$ 14,596,000,000$, as compared with an assessed valuation of all tax-exempt realty of $\$ 2,997,000,000 .^{76}$ In that year the percentage ratio of tax-exempt real property to taxable real property was 20.5 per cent. In 1925 the percentage ratio had risen to 23.8 per cent but an important new nonreligious tax exemption had been added in the meantime. ${ }^{77}$ In 1930 the percentage ratio had decreased slightly to 22.9 per cent. $^{78}$

7N. Y. Times, Aug. 29, x937, p. I, col. I.

${ }^{76}$ N. Y. Times, April 19, 1947, p. I, col. 4. Mr. Ford's will is completely set forth in id. at p. 2r, col. 2. Also by use of a charitable trust, businesses sometimes obtain competitive advantages through the income tax exemption. See Investigation of Closing of Nashta, N. H. Mills and Operations of Texiron Incorporated, Report of Subcommittee on Interstate and Foreign Commerce, United States SENATE, 8Ist Cong., ist Sess. (1949). Apparently religious organizations have seldom been made beneficiaries of such trusts.

${ }^{78}$ Spectal Jont Commitiee on Taxation and Retrenchment, Tax Exemption in State of New York 37 (1927).

Ir 1 bid.

${ }^{78}$ BAILEY, TAX EXEMPTION-IN NEW YORK I5 (1932). 
These valuations comprise all the tax-exempt property in the state of New York, including therefore not only the property of private charitable, religious, and educational institutions but also property owned by governmental units, federal, state, and local. In I920 property held for religious purposes comprised rr.8 per cent of all tax-exempt property. In 1925 the percentage of religiously held property decreased to II.3 per cent ${ }^{7 \theta}$ and in $x 93^{\circ}$ it was only Io per cent of the total tax-exempt property. ${ }^{80}$ Again it should be noted that beginning in 1925 an important private but nonreligious tax exemption was involved in the computation.

On the level of local government, the table below indicates that the percentage of tax-exempt property in the city of Yonkers, New York, which is exempted because of its religious use, has remained between 8 per cent and ro per cent of the total taxexempt realty over a period of ten years. ${ }^{81}$

$\begin{array}{cccc}\text { Year } & \begin{array}{c}\text { Total Real Estate } \\ \text { Valuation }\end{array} & \begin{array}{c}\text { Total Exempt } \\ \text { Property }\end{array} & \begin{array}{c}\text { Religious Exempt } \\ \text { Property }\end{array} \\ \text { I940 } & \$ 287,544,550 & \$ 89,389,685 & \$ 8,116,150 \\ \text { I943 } & \$ 272,711,915 & \$ 76,093,485 & \$ 6,206,250 \\ \text { I946 } & \$ 268,881,025 & \$ 7 I, 797,525 & \$ 6,190,275 \\ \text { I949 } & \$ 291,258,440 & \$ 73,253,335 & \$ 6,407,750\end{array}$

In trying to discover the effect of tax exemptions in general, a New York legislative committee examined twenty-one cities, towns, and villages which showed an abnormal amount of tax-exempt property. The committee's research staff discovered no serious tax hardship to those cities, towns, and villages. In addition, a statistical examination of governmental costs and tax rates in these cities and towns revealed no correlation between the amount of tax-exempt property in a given city or town and either the cost of government or the local tax rate. ${ }^{82}$

These figures, state and federal, indicate that both the tax deductions for charitable, educational, and religious purposes and the public and private exemptions may well concern tax gatherers. But in so far as information is available, the religious deductions and exemptions do not seem to be the most important segment of the problem. ${ }^{83}$ This may well be the reason for the limited amount of present-day criticism of organized religion's freedom from taxation. Few problems achieve great public importance until they become economically significant.

Without reference to statistical proof, if religious institutions (and charities and educational institutions) paid taxes, more tax money would be available and the rate for other taxpayers should be lower. Where part of the wealth of a community is

${ }^{70}$ Special Joint Committee, op. cit. supra note 76 , at $4 \mathrm{~T}$.

${ }^{80}$ BaILEX, op. cit. stipra note 78 , at I7.

${ }^{81}$ The information upon which this table was based is taken form a statistical chart supplied the author by the City of Yonkers Department of Assessment and Taxation.

${ }^{82}$ Special Joint Commitee, op. cit. supra note 76 , at 13 et seq.

${ }^{83}$ Professor Robert Haig comes to the same conclusion: "Contrary to the general impression, exemptions to religious and charitable institutions do not bulk large in the aggregate figures." REPORT OF THE New York State Commission for the Revision of the Tax Laws i2i (1932). 
not taxed the rest of the community must bear the whole cost of government. Yet apparently it is very difficult to make out a convincing factual case for eliminating religious tax exemptions and deductions on the basis of the existing economic data.

\section{$\mathrm{V}$}

\section{LABOR LegisLation}

The state may prefer an institution by relieving it of burdens other than those of taxation. In many instances religious organizations are excluded from the coverage of laws regulating labor and labor relations. Obviously, the church is not a commercial institution employing a vast number of workers. Therefore, the total impact of religious exemptions does not play an important role in labor problems. From these exemptions, however, important questions concerning the relationship between the church and the community arise.

Perhaps the earliest and certainly the most famous of cases excluding religious institutions from a labor regulation is that of Church of the Holy Trinity v. United States. ${ }^{84}$ The hiring of an Anglican clergyman, a non-resident alien, was held not to violate a federal statute forbidding the importation of aliens under contract to perform labor or "service" of any kind. The grounds given were two: (I) The evil against which the statute was directed was the undercutting of American laborers' wages by the mass importation of foreign workers by factory owners, and employment of a clergyman was not within the statute's ban; (2) the Congress of the United States, a nation basically Christian, could not be supposed to have legislated against religion. Although the words of the statute were clearly broad enough to cover this contract of employment, it would seem equally clear that the contract was not within the statute's purpose. There is no reason to believe that the domestic market for Anglican clergymen was being seriously threatened by foreign competition. Consequently, the decision in the case is sound-just as it would have been in the case of a bank which had imported a Spanish president or a university which had imported a French dean. The second ground of decision is superfluous.

A decision contrary to the result actually reached in the Holy Trinity case would have raised an interesting question concerning the relationship of the church to the state. According to the terms of the First Amendment, the Congress has no power to make laws prohibiting the "free exercise" of religion. In general the conduct of religious services requires clergymen. In most Protestant denominations the right to select a minister is a very important part of the freedom to worship. When a clergyman, as an individual, can meet the requirements of the immigration statutes, would it not be a serious impairment of the "free exercise" of religion to penalize his church merely for hiring him before his immigration into the United States?

Workmen's compensation acts imposing liability without fault upon employers for injuries to employees incurred in the course of employment frequently have been

${ }^{86} 143$ U. S. 457 (1892). 
construed to exclude the employees of religious institutions. This interpretation is usually placed on the ground that the religious institution is not an organization which exists for "pecuniary gain," 85 nor is it engaged in business for profit. Some states limited the coverage of their workmen's compensation acts to profit-seeking enterprises. Religious institutions are correctly classified as outside the scope of these acts.

The labor relations acts of Connecticut ${ }^{86}$ and New York ${ }^{87}$ expressly except religious institutions from their respective coverage. The relevant provision of the New York State Labor Relations Act was held inapplicable to the employees of educational, charitable, and religious institutions not only when engaged in institutional activities, but also when engaged in any type of work for the exempted organization. Specifically, workers in a commercial loft building owned by Columbia University, located several miles from the campus and used for non-educational purposes, were found to be beyond the reach of the New York Labor Act. ${ }^{88}$ This decision expanded the practical effect of the statutory exclusion immeasurably. In I946 the statute was amended to exclude only those employees actually engaged in the principal activities of the exempted organization. ${ }^{89}$

In Pennsylvania and Massachusetts State Labor Relations Acts, which contain no express exception, were held inapplicable to charitable hospitals. ${ }^{90}$ Even then, however, the implied exemption recognized in the Pennsylvania case would not seem to extend to religious organizations except in so far as they operate hospitals. ${ }^{01}$ The opinion in the case evidenced great concern with the effects of labor disturbances in a hospital and the consequent serious results of a disruption in service. No similar problem is involved in the conduct of a solely religious organization. The Massachusetts opinion exempted the hospital because it was not engaged in industry or trade, a ground equally applicable to churches.

There are no convincing reasons why the employees of a religious association

${ }^{85}$ Dillon v. Trustees of St. Patrick's Cathedral, 234 N. Y. 225, I37 N.E. 3 II (I922); Gardner v. Church of Ottumwa, 2I7 Iowa I390, 250 N.W. 740 (r933). The present New York State statute will include a minister of religion. See Walker v. Calvary English Lutheran Congregation, 264 App. Div. 965,37 N. Y. S. $2 d 59$ (3d Dep't. 1942).

${ }^{80}$ Conn. Gen. Stat. c. 279, \$933h (Supp. I945). $\quad{ }^{87}$ N. Y. Labor LAW \$715.

${ }^{88}$ Columbia University v. Herzog, 269 App. Div. 24,53 N. Y. S. $2 d 6 \mathrm{r} 7, a f f^{\prime} d, 295$ N. Y. 605,64 N. E. $2 \mathrm{~d} 35 \mathrm{I}$ (1945).

${ }^{80}$ N. Y. Laws c. 463 (1946).

${ }^{00}$ Western Pennsylvania Hospital v. Lichliter, 340 Pa. 382, I7 A. 2d 206 (I94x); St. Luke's Hospital v. Labor Rel. Comm'n, 320 Mass. 467,70 N. E. $2 d$ zo (r946). The Pennsylvania case was not followed in Northwestern Hospital v. Public Bldg. Service Employees' Union, 208 Minn. 389, 294 N. W. 215 (1940), nor in Wisconsin Emp. Rel. Bd. v. Evangelical Deaconess Society, 242 Wis. 78,7 N. W. 2 d 590 (1943). However, the New York Anti-Injunction statute has been held inapplicable to protect employees of a hospital: Jewish Hospital of Brooklyn v. Doe, 252 App. Div. 58r, 300 N. Y. Supp. IIII (r937). A hospital in the District of Columbia has been held subject to the N. L. R. A.: National Labor Relations Board v. Central Dispensary \& Emergency Hospital, r45 F. 2d 852 (App. D. C. r944). Cf. Pagel v. Trinity Hospital Ass'n, 72 N. D. 262, 6 N. W. 2 d 392 (1942) (holding employees to be outside the scope of an administrative order defining the coverage of a state minimum wage law).

os However, the exception has been extended in Pennsylvania to include the activities of the Salvation Army. Petition of Salvation Army, 349 Pa. 105, 36 A. 2d 479 (1944). 
should be deprived of the same statutory protection in organizing labor unions that is given workers in other enterprises. The presumed fairness with which a charitable or religious employer deals with its employees has been suggested as a reason. ${ }^{02}$ There seems to be little evidence, however, that a church janitor needs the advantages of union organizations less than a janitor employed in an apartment building. Perhaps contributions to religious organizations will diminish if the contributors observe that the religious organization bargains collectively with its employees. ${ }^{93}$ But this is the most tenuous sort of speculation. The general encouragement of religious organizations by freeing them from laws designed to benefit workmen is certainly a doubtful policy.

The statutes of some states which have adopted a fair employment practices act do not include the employees of religious institutions. ${ }^{94}$ In so far as a state F. E. P. A. forbids discrimination in employment because of religious affiliations, the statutory exception is quite understandable. Few people would force a Roman Catholic organization to employ Protestant workers, or a Jewish congregation to employ a Catholic janitor. The practice of using church jobs as a kind of charity is too common.

The issue becomes more doubtful when discrimination in employment is based on race. Fair Employment Practices Acts permit employers to discriminate in employment which is thought to be personal or intimate in nature, as, for example, that of a domestic servant. The employment of a clergyman may create a similarly intimate relationship to his congregation. Yet this rationale of the exemption would seldom apply to the employment by a church of an unskilled workman. It is difficult to understand why a religious organization any more than any other should be permitted to discriminate in employment on racial grounds.

The Old Age and Survivors Insurance section ${ }^{95}$ of the federal Social Security Act, as well as the Unemployment Compensation provisions, ${ }^{96}$ expressly exclude the employees of religious institutions. Yet the basic public policy behind these laws calls for the protection of the employees of religious institutions equally with that of any other employed group. Employees of churches grow old, become unemployed, and create problems for society in the process. The principal reason for placing these employees outside the coverage of the Social Security Act probably stems from the traditional exemption of churches from taxation. Both sections of the Social Security Act require the levying of taxes upon employers. The churches fear the first step toward loss of their tax immunity. ${ }^{97}$

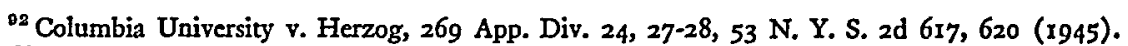

${ }^{23}$ Ibid.

${ }^{24}$ Mass. Acts (1946) c. 368, $\$ 4$ ( $\$ 1$, pt. 5, of a new chapter, I5IB, Mass. Gen. Laws); N. J. Laws (1945), c. I69, \$5(e); N. Y. Laws (1945) c. I18, \$127(5).

${ }_{95} 49$ Stat. 639 (1935), 42 U. S. C. \$roIr(b)(8) (1940).

${ }^{96} 49$ STAT. 643 (1935), 42 U. S. C. $\$ 1107$ (c)(7) (1940).

${ }^{97}$ See Montavon, Old Age and Survivors Insurance (National Catholic Welfare Conference 1946): "The uncertain cost of Social insurance, which tends to expand, as well as the fact that the traditional 
All these labor regulations have as their principal purpose the protection of workmen in their employment and the maintenance of their economic security. Therefore, in relieving religious organizations from the social obligations of these statutes, the state is favoring religious institutions at the expense of rights which workers enjoy in other areas of economic activity. This favoritism is much less justifiable than the indirect financial support which the church receives through tax exemption. In the case of tax exemptions, all taxpayers of the community are required to supply the funds necessary to finance the business of government. The exemption of the church from taxation increases the total burden placed upon the entire taxpaying community. By excepting educational, charitable, and religious institutions from the operation of labor legislation, however, the state is favoring those institutions at the expense of relatively small numbers in the community. The employees of religious groups are required to surrender their rights to organize, their freedom from unjust discrimination, and their protection against the hardships of old age and unemployment.

Most employees of charitable and religious institutions take their jobs in order to earn a living. Except for the clergy and a few other professional workers, the job is taken with no sense of dedication to charity or religion. It can reasonably be doubted that workers employed by charitable or religious institutions are better paid or better cared for than employees of an automobile plant. ${ }^{98}$ The need for legal protection is not diminished by the charitable or religious character of the employer.

tax-exempt status would be jeopardized, have deterred voluntary tax-exempt organizations from demanding that their employes be not denied by law the right to share in the benefits of Old Age and Survivors Insurance."

${ }^{08}$ The need which employees of charitable or religious institutions have for legislative protection is recognized in the remarks of Judge Pecora in Society of New York Hospital v. Hanson, I85 Misc. 937, 946, 59 N. Y. S. 2d 9r, 99 (1945): "The vital factor is that the public interest, which the legislature must have deemed to be served by denying employees of such institutions the fundamental rights which labor, in the face of bitter opposition, has through the years fairly won in its dealings with private employers, may be better served by the enactment of legislation insuring these employees of fair treatment in their relations with their employers, - such legislation, for instance, as may provide for minimum wage scales, hours of labor and arbitration boards to determine disputes." 